\title{
Neutrophil-to-lymphocyte Ratio and Platelet-to-lymphocyte Ratio as an Inflammatory Biomarker in Predicting the Severity of Secondary Brain Injury: A Review Article
}

\author{
Gede Febby Pratama Kusuma ${ }^{1 *}$, Sri Maliawan², Tjokorda Gde Bagus Mahadewa², Tjokorda Gde Agung Senapathi ${ }^{3}$ \\ ${ }^{1}$ Master Postgraduate Program, Faculty of Medicine, Universitas Udayana, Bali, Indonesia; ${ }^{2}$ Department of Neurosurgery, \\ Faculty of Medicine, Universitas Udayana, Bali, Indonesia; ${ }^{3}$ Department of Anesthesiology and Intensive Care, Faculty of \\ Medicine, Universitas Udayana, Bali, Indonesia
}

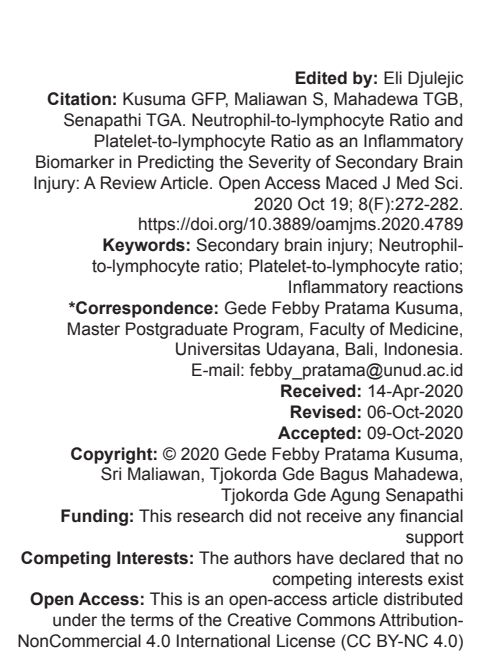

\section{Abstract}

Traumatic brain injury (TBI) is one of the leading causes of death and disability, which affects millions of people globally with a significant economic burden. The inflammatory reactions and immune system activity play a significant role in the severity development of secondary brain injury (SBI) after a TBI event. Neutrophils, platelets, and lymphocytes are involved in these inflammatory reactions and have potential in reflecting the severity level of SBI that occurred post-TBI. Some recent studies have shown that the neutrophil-to-lymphocyte ratio (NLR) and platelet-to-lymphocyte ratio (PLR) can be used as a potential biomarker for determining the severity of an inflammatory reaction, including SBIs in post-TBI. However, the results of NLR and PLR in TBI patients in daily medical practice are still not fully utilized. This review summarizes the neutrophil's, platelet's, and lymphocyte's role in SBI, also the NLR and PLR potential as a marker of the severity of the SBI process in TBI cases.

\section{Introduction}

Traumatic brain injury (TBI) is one of the leading causes of death and disability, which affects millions of people globally with a significant economic burden [1]. It can lead to impaired cognitive and physical functions that can be suffered by the patients for the rest of their life. Those problems may cause the patients to spend costs and efforts because they require prolonged treatment and rehabilitation to recover their disability [2]. Therefore, comprehensive initial management is needed, which includes the biomarker examination that can predict the severity of secondary brain injury (SBI) in TBI patients. Thus, the effectiveness of the TBI's treatment can be increased, and the progression of the $\mathrm{SBI}$ in TBI cases can be prevented.

TBI is an injury caused by the external mechanical force to the cranium and its intracranial components, thus alters the brain structures and functions [3]. The pathologic processes that occur in the TBI consist of the primary and SBI [4]. Primary brain injury is caused by the exposure of mechanical force to the brain tissue, which leads to axonal damages, vascular damages, and glial cells damages. A SBI is caused by the occurrence of the inflammatory cascades that are initiated by the release of various inflammatory factors and neurotransmitters from the damaged neuronal and glial cells in the brain [5].

$\mathrm{SBI}$ is sensitive toward the treatment, and its processes can be prevented. SBI is an essential therapeutic window and can determine whether the development and recovery of the TBI are good or bad [5]. The increase in the systemic inflammatory response can be reflected from increased inflammatory cells, such as neutrophils, or the increase in the level of the inflammatory biomarkers, such as $\mathrm{C}$-reactive protein (CRP) and erythrocyte sedimentation rate (ESR) [6], [7]. CRP and ESR are already commonly used to monitor the progression of inflammatory diseases, but these laboratory examinations have not been routinely done in traumatic patients. Moreover, CRP and ESR 
examinations are also not always available in every hospital.

On the other hand, the neutrophils, platelets, and lymphocytes count can be obtained through a complete blood count (CBC), which is more routinely done compared to the CRP and ESR laboratory examinations in the traumatic patients. The CBC examination is used primarily to monitor the bleeding that occurs due to trauma through the hemoglobin's and hematocrit's level. The CBC test is also available in every hospital, even in some rural areas. A CBC test is undoubtedly a cheaper and more available laboratory examination in daily medical practice [8].

Some recent studies have shown that the neutrophil-to-lymphocyte ratio (NLR) is very easy to be measured and can act as a predictor of clinical outcomes from cancer, cardiovascular, and stroke diseases [9], [10], [11]. Besides NLR, the platelet-tolymphocyte ratio (PLR) can also act as a potential marker for determining the severity of an inflammatory reaction [7]. Moreover, a study found that NLR and PLR are positively correlated with high sensitivity CRP (hs-CRP) and ESR in patients with autoimmune inflammatory disease, such as Takayasu's Arteritis [7]. However, the predictive value of NLR and PLR in TBI cases is still unclear and has not been extensively explored.

Theoretically, NLR and PLR have the potential to be used as a marker of the severity of the SBI process that occurs in TBI. However, the results of NLR and PLR in TBI patients in daily medical practice are still not fully utilized. This review will summarize the neutrophil's, platelet's, and lymphocyte's role in SBI, also the NLR and PLR potential as a marker of the severity of the SBI process in TBI cases.

\section{Methods}

This article used a literature review method. Journals from various accredited and online-based sources such as PubMed and Google Scholar database are collected using the following keywords: NLR, PLR, TBI, SBI, inflammation, neutrophil, platelet, and lymphocyte. A total of 110 articles relevant to the topic were included and reviewed for the analysis and synthesis process.

\section{Results and Discussion}

\section{SBI}

SBI begins immediately after the primary brain injury and can trigger a series of events that cause cerebral edema, cerebral ischemia, and even death or persistent vegetative condition [12], [13]. The immune system activity and inflammation response have been proved as the crucial factors in initiating and developing the SBI processes to a more severe state postTBI [14], [15]. Cells such as neutrophils, astrocytes, and microglia are involved in the acute inflammation reactions post-TBI [16].

Under physiologic conditions, the brain is an organ that has special immunity due to the presence of blood-brain barrier (BBB), a limited number of antigenpresenting cells (APC), and a few apparent lymphatic vessels [17]. However, TBI can cause direct damage to the BBB, which allows the entry of massive amounts of peripheral APCs, as well as activation of microglia in the damaged brain [4], [18]. In addition, the latest research shows another new passage through the lymphatic blood vessels in the central nervous system's (CNS) meninges for the peripheral immune cells to enter the brain's tissue back and forth [19]. All of these things can interfere with the balance of the CNS's immune system environment, which can cause communication between the peripheral immune system and the CNS in TBI [20].

The damaged blood vessels will cause the blood to come out of the blood vessels, thereby disrupting the blood supplies and BBB integrity in the brain's tissue. The damaged neurons and glial cells also can induce an inflammatory cascade response by releasing various inflammatory factors and neurotransmitters post-TBI. Processes that can occur in the SBI include aggravate of the BBB damages, change in the blood flow (ischemia, bleeding), neuroinflammation, dysfunction of the metabolism in the brain's tissue (edema and hypoxia), and cell damage (oxidative stress, excitotoxicity, production of free radicals, and apoptosis/necrosis of the neurons) [5].

\section{Neutrophil's roles in SBI}

Neutrophils are the primary component in the innate immune system that plays an essential role in the acute inflammation against pathogens and can cause tissue damages indiscriminately [5]. Due to the role of the BBB, there are only a few amounts of neutrophils that can be found in the brain's parenchyma [21]. However, pathological conditions such as trauma, bleeding, ischemia, and infection can cause an increase in the number of neutrophils that enter the brain's tissue [17].

External factors, such as trauma and stress, as well as internal factors, such as granulocytemacrophage-colony stimulating factor (GM-CSF) and granulocyte-CSF (G-CSF), can modulate the neutrophil's activity [22], [23], [24]. These factors will make the neutrophils undergo the differentiation and maturation processes, which include the changes in the level of expression of the neutrophil's membrane proteins that are very crucial for neutrophils to sense the infection or danger signals; thus neutrophils 
are able to move toward the target tissue and phagocytose the tissue debris [5]. These factors also increase the expression of various granule proteins in the neutrophils which are useful to eliminate the pathogens such as matrix metalloproteinases (MMPs), neutrophils elastase (NE), myeloperoxidase, and neutrophils gelatinase-associated lipocalin [25], [26]. The accumulation of neutrophils to eliminate pathogens through phagocytosis and degranulation processes is the first line of the immune system (innate immune system), but it can aggravate the tissue damages and $\mathrm{SBI}$ if too excessive [5].

The damaged brain's parenchyma post-TBI can release inflammatory cytokines such as tumor necrosis factor (TNF)- $\alpha$, interleukin (IL)-1 $\beta$, CXCL1, CXCL2, and CXCL5, which further activate the neutrophils and endothelial cells and facilitate the migration of the neutrophils into the CNS parenchyma [27], [28]. TBI also induces vascular damages in the brain, including the BBB. The activated neutrophils will accumulate in the damaged cortical and the disrupted BBB area within 12-h post$\mathrm{TBI}$, then migrate to the surrounding brain parenchyma within 24-h post-TBI [18]. The activated neutrophils can damage the tight junction and permeability of BBB by degrading the zonula occludens- 1 , vinculin, occludin, and $\beta$-catenin, which are very important for maintaining the integrity of BBB [5]. The NE and MMPs released by neutrophils can interfere the cadherin-cadherin bond, degrade the neurovascular structures and dysregulate the $\mathrm{BBB}$, thus induce the hyper-permeability of the BBB [29], [30], [31], [32]. The activated neutrophils also release free radicals such as reactive oxygen species (ROS) and nitrous oxide, which induce the direct oxidative damages and disrupt the arrangement of claudin- 5 and occludin in the endothelium, thus impair the integrity of BBB [33], [34]. The BBB damages due to neutrophils activity will facilitate the immune cell's recruitment into the brain parenchyma to fight against pathogens. However, it can also aggravate brain damages and SBI at the same time.

Neutrophils are also involved in the process of cerebral edema post-TBI. Cerebral edema is a state caused by the excessive fluid accumulation in the intracellular or extracellular spaces of the brain's tissue, which causes expansion or swelling of the brain's tissue in a limited skull cavity. It can increase the intracranial pressure, interfere with the brain's perfusion and oxygenation, and contribute to a more severe ischemic injury post-TBI [35]. Neutrophils are tightly related to cerebral edema in the SBI process post-TBI. The BBB damages, which are caused by neutrophils activity, enable the protein and intravascular fluid to enter and accumulate in the extracellular space of the brain's parenchyma, thus lead to cerebral edema [36]. In addition, granules that released by neutrophils such as elastase, lipoxin, and azurocidin can increase the vascular permeability, thus can also aggravate the cerebral edema [37], [38].
The activated neutrophils can also contribute to the imbalance between cerebral oxygen delivery and cerebral oxygen consumption in SBI post-TBI because they will consume more oxygen to produce and release the NADPH oxygenase-related molecules, hydrogen peroxide superoxide, and antibacterial proteins such as defensins and cathelicidin for maintaining its phagocytic function [4], [18], [33], [39]. Changes in the volume and rate of the cerebral blood flow and the arterial oxygen content post-TBI can interfere with the oxygen delivery, causing the injured area of the brain to experience a more hypoxic condition [5]. A previous study showed that the expression of NFkB and hypoxia-inducible factor- $1 \alpha$ could be induced by the low oxygen levels, which cause prolonged neutrophils survival and their activation [40]. Meanwhile, neutrophils themselves can also cause overproduction of ROS by the autocrine IL-17 pathway, which can aggravate the SBI due to ROS [41]. In addition, the clinical outcome of TBI patients is also correlated with the duration and severity of cerebral hypoxia that occurs in the SBI process [42]. Thus, the more neutrophils that activated in SBI post$\mathrm{TBI}$, the more cerebral hypoxia will occur, and the worse clinical outcome post-TBI will be.

Another crucial role of neutrophils in SBI is involved in the neuroinflammation process. Neuroinflammation is an inflammatory response in the CNS due to the reaction of brain cells and peripheral immune cells toward a stimulus or injury. Even though this response occurs to protect the CNS from damages and infections, neuroinflammation is also an essential mechanism to initiate the SBI process post-TBI [5]. Neuroinflammation due to $\mathrm{TBI}$ is characterized by the activated glial cells, leukocyte recruitment, and increased inflammatory cytokines regulation in the brain [43].

TBI can activate the microglia, which then induce the activation of endothelial cells and the peripheral leukocytes recruitment into the brain's tissue [44]. The activated microglia post-TBI will rearrange the expression pattern of their receptors and also release essential inflammatory mediators that are powerful for recruiting and activating neutrophils such as IL-1 $\beta$, IL-6, CXCL1-5, CXCL8-10, and TNF- $\alpha$ [45]. Moreover, neutrophils themselves can also release molecules such as MMP9, lipocalin 2, and ROS, to mutually activate the microglia in an amplification cascade manner [46], [47], [48].

Astrocyte is also a glial cell that is the main constituent of the CNS. Astrocytes are essential for maintaining the CNS homeostasis and contributing to the integrity of BBB [5]. In TBI, neutrophils and astrocytes are closely linked and respond to each other to the cytokines that are released. Astrocytes are an essential source of cytokines such as IL-6, MMP2, MMP9, GM-CSF, CXCL1, CXCL2, CCL2, and chemokines containing glutamate-leucine-arginine motive [49]. Cytokines such as CXCL1, CXCL2, and 
GM-CSF can increase the BBB disruption, increase the leukocyte recruitment, and initiate the inflammatory process [50], [51], [52]. IL-1 $\beta$ and TNF- $\alpha$ can inhibit the uptake of glutamate by astrocytes, thus aggravate the neuroinflammation [53]. Based on these data, neutrophils and astrocytes have an essential role in the neuroinflammation process as the primary source of cytokines and also exacerbate the inflammatory cascade reciprocally [5].

The activated neutrophils are able to release various chemokines and molecules that can affect the process of SBI (Table 1) [5]. After the danger signal disappeared, neutrophils are still challenging to be immediately stopped because they can also strengthen their activation through the autocrine mechanisms [56], [69], [70]. This process makes the neutrophils have the potential to indiscriminately damaged the brain's tissue and aggravate the SBI in TBI. Thus, to minimize the tissue damages after the digestion process of the pathogens by the neutrophils, most of the neutrophils are phagocytosed or inhibited by lymphocytes [5].

Table 1: Various chemokines and molecules released by the activated neutrophils that can affect the process of SBI

\begin{tabular}{|c|c|c|}
\hline Name & Effect & Reference \\
\hline IL-1a & Associated with BBB damage and neuronal death & [54] \\
\hline IL-1 $\beta$ & Induces neuronal death directly & [54] \\
\hline IL-9 & Exacerbates the excitotoxic brain damage & [55] \\
\hline IL-18 & $\begin{array}{l}\text { Induces brain damage and induces neutrophils to secrete } \\
\text { inflammatory cytokines }\end{array}$ & [56] \\
\hline IL-23 & Causes brain damage and neurological deficits & [57] \\
\hline CXCL1 & Recruits neutrophils to the injured brain & [58] \\
\hline CXCL2 & $\begin{array}{l}\text { Facilitates the chemotaxis of polymorphonuclear leukocytes } \\
\text { (PMN), peak in 4-h post-TBI }\end{array}$ & [59] \\
\hline CXCL3 & $\begin{array}{l}\text { Facilitates the migration of neutrophils through the epithelial } \\
\text { barrier }\end{array}$ & [60] \\
\hline CXCL5 & $\begin{array}{l}\text { Increases microglia activation and BBB damage disrupt } \\
\text { myelination }\end{array}$ & [61] \\
\hline CXCL8 & Helps neutrophils to infiltrate the brain parenchyma & [62] \\
\hline M-CSF & Increases microglia activation & [63] \\
\hline TNF- $\alpha$ & $\begin{array}{l}\text { Induces astrocytes to secrete IL- } 6 \text { and IL-8, mediates the } \\
\text { PMN neurotoxicity directly }\end{array}$ & [64] \\
\hline ROS & $\begin{array}{l}\text { Increases BBB dysfunction, causes neuronal cell death and } \\
\text { microglia activation }\end{array}$ & [33] \\
\hline MMP9 & $\begin{array}{l}\text { Damages BBB integrity, increases neutrophils infiltration and } \\
\text { PMN neurotoxicity }\end{array}$ & [65] \\
\hline MPO & Reflects the neutrophil infiltration in the brain tissue & [66] \\
\hline Cathepsins & $\begin{array}{l}\text { Causes cell death through programmed cell necrosis and } \\
\text { the mitochondrial apoptotic pathway }\end{array}$ & [67] \\
\hline $\mathrm{NE}$ & Induces acute neuronal death and cellular stress & [68] \\
\hline
\end{tabular}
factor, MMP: Matrix metalloproteinases, NE: Neutrophils elastase, MPO: Myeloperoxidase, TNF: Tumor necrosis factor, IL: Interleukin, ROS: Reactive oxygen species.

\section{Platelet's roles in SBI}

As mentioned previously, the immune system activity and the inflammatory response have been proven to play an important role in the initiation and development of the SBI process post-TBI to a more severe level [14], [15]. Not only neutrophils, astrocytes, and microglia but also platelets, which play an essential role in the immunomodulatory and inflammatory process, are involved in the acute inflammatory reaction post-TBI [8], [16], [71].

Thrombopoiesis process is regulated by thrombopoietin and other various inflammatory cytokines, such as IL-1, IL-3, IL-6, GM-CSF, and
TNF- $\alpha$ [72], [73]. Thrombopoietin is produced by the parenchymal and sinusoidal endothelial cells in the liver, and its production is increased in the presence of IL-6, which level also increased in the neuroinflammation processes post-TBI [45], [49], [74]. Platelets can also induce the release of inflammatory cytokines and interact with various cells, including neutrophils, macrophages, and T-lymphocytes, that will have an impact on the initiation or exacerbation of the inflammatory process [75], [76]. Therefore, the high number of platelets can reflect an increased release of inflammatory cytokines and platelet activation, which lead to increased inflammatory response and worsened SBI post-TBI [77].

Platelets play an active role in the inflammatory process [7]. Several other factors are also responsible for the platelet activation and the release of platelet's pro-inflammatory and prothrombotic molecules such as systemic inflammation and oxidative stress [78]. Inflammatory cells and bioactive molecules, such as IL-6 and CRP, can change the morphology and reactivity of platelets released from the bone marrow [79]. In the presence of stressor conditions, such as trauma, there is a positive correlation between thrombopoietin, ploidy from the platelet's progenitors, platelet's functional activity, and high platelet's count [80]. It is often seen in the inflammatory disorders, where an increased thrombopoiesis causes an increased number of platelets in the circulation, and a high number of very reactive large platelets migrate to the sites of inflammation [81].

A higher platelet's count can reflect the level of the ongoing inflammatory process and can also become a marker of the ongoing destructive inflammatory response and prothrombotic status, because of some inflammatory mediators can stimulate the proliferation of megakaryocytes, thus resulting in thrombocytosis [8]. A positive correlation was also found between the acute phase reactants and proinflammatory proteins (CRP, TNF- $\alpha$, IL-1, and IL-6) with an increased platelet's count in the inflammatory conditions [82], [83]. Many studies about chronic inflammation from arthritis have found that there is an increase in platelets activation [84], [85]. The evidence of experimental and clinical researches also showed that there are some involvements of platelet-derived compounds in the inflammatory diseases such as systemic lupus erythematosus (SLE), rheumatoid arthritis (RA), and other related thrombotic complication diseases [86], [87], [88].

In vascular diseases, such as atherosclerosis, platelets can interact with leukocytes and are considered as the central factor in the pathophysiology of vascular inflammation. The increased circulating platelet mass can be caused as a consequence of the presence of chronic inflammation. The activated platelets do not only produce growth factors such as platelet-derived growth factor and transforming growth factor- $\beta$ but also release chemokines that have an essential effect on the vascular inflammation, thus triggering thrombosis [89]. Platelets have intracellular thromboxane A2 and 
procoagulant surface proteins such as P-selectin and glycoprotein IIIa, so they have the potential to cause thrombosis if they are overactivated [90]. In addition, inflammation by itself can induce the occurrence of procoagulant processes and facilitate embolization, which is one of the leading causes of death [75].

\section{Lymphocyte's roles in traumatic injury}

In response to the physiological stresses, such as a traumatic injury, the body will release more cortisol hormone, which if the level is high, it can cause lymphopenia [91]. The higher the physiological stress level, the higher the cortisol level, thus, the lower the lymphocyte's count in the body. In contrast, the higher lymphocyte's count represents a more precise immune response and a more stable inflammatory pathway [92]. In cancer diseases, lymphocytes are responsible for the programmed cell death or apoptosis process [93]. Lymphocytes reflect a more controlled inflammatory pathway, and the lymphocytes-mediated apoptosis is less destructive to the surrounding cells compared to other models of cell death due to uncontrolled inflammation [8]. Therefore, the lower the lymphocyte's count post-TBI can reflect an increasingly destructive effect of the inflammatory response, which leads to a worsened SBI post-TBI.

\section{$N L R$}

NLR is a reflection of the degree of the inflammatory response (neutrophils) and immune status (lymphocytes), which shows an increase in the recruitment of inflammatory cells and the release of inflammatory cytokines when NLR level increases [94], [95]. Neutrophils are recruited into the site of injury in the brain within 1-h post-TBI and are able to release inflammatory mediators that can induce neuronal death and SBI [96], [97]. The increase in the peripheral neutrophils amount can increase the BBB damage, brain's tissue damage, and neuronal cell death, which then further aggravating the inflammatory reactions and brain tissue damage, thus increasing the severity of SBI [98].

NLR can be obtained from the CBC laboratory examination, is very easy to be measured, and can act as a predictor of clinical outcomes from cardiovascular diseases, stroke, and cancer [9], [10], [11]. Several studies have also found that high levels of NLR are associated with autoimmune diseases such as RA, SLE, psoriasis, ulcerative colitis, Sjogren's syndrome, and Behcet's disease [99], [100], [101], [102], [103].

A study found that a high NLR level in patients with spontaneous intracerebral hemorrhage $(\mathrm{sICH})$ is significantly associated with the incidence of in-hospital mortality and mortality on the $90^{\text {th }}$-day [95]. It also found that the NLR level above 7.5 in patients with $\mathrm{sICH}$ had statistically significant potential for predicting the poor clinical outcomes(a Modified Rankin Scale from 3 to
6 was considered a poor outcome) and mortality [95]. Another study found that intracerebral hemorrhage patients with NLR level above 7.35 are associated with poor short-term survival(30-day mortality) and had a higher rate of intraventricular hemorrhage(hyperdense intraventricular signal not attributable to calcification or choroid plexus from computed tomography [CT]-scan images), ICH volume(from CT-scan images, calculated using ABC/2 formula), and lower GCS score compared to the intracerebral hemorrhage patients with NLR level 7.35 or lower [11]. In some other studies, they found that the NLR level can also be used as a prognostic factor to predict the clinical outcome (using Glasgow Outcome Scale/GOS score) and mortality of TBI patients in the $6^{\text {th }}$-month and $1^{\text {st }}$-year post-TBI, where a high NLR level is associated with poor clinical outcome(GOS score 1-3) in TBI patients [104], [105], [106]. Moreover, a study found that NLR is positively correlated with hs-CRP and ESR in patients with Takayasu's arteritis, which is an autoimmune inflammatory disease [7]. Thus, NLR has the potential and can be used as a promising inflammatory biomarker in predicting the severity of SBI post-TBI.

\section{PLR}

PLR can be used as a potential marker for determining the severity of an inflammatory reaction because platelets play an important role in the immunomodulatory and inflammatory processes [7], [71]. PLR is useful as a prognostic marker of the inflammatory response of several diseases such as intracranial hemorrhage, pulmonary embolism, cardiovascular diseases, cancer, and inflammatory diseases [77], [85], [107], [108], [109].

A study found that in intracranial hemorrhage patients, PLR is more superior in predicting the neurological outcome(using GCS at hospital discharge and Modified Rankin Scale at 6-month as the short-term and long-term neurological outcomes) and is more accurate in reflecting the severity of inflammatory reactions compared to the number of platelets or lymphocytes count alone [77], [110]. It also found that intracranial hemorrhage patients with a high PLR level, when admitted to the intensive care unit room, are significantly associated with a worse patient's GCS at hospital discharge [77]. Another study found that Takayasu's arteritis patients and patients with an active Takayasu's arteritis have a higher PLR level compared to the healthy patients and patients with Takayasu's arteritis in remission [7]. It also found that a high PLR level had been proved as an indicator of an increased inflammatory response associated with Takayasu's arteritis [7]. Moreover, it is also found that PLR is positively correlated with hs-CRP and ESR in patients with the autoimmune inflammatory Takayasu's arteritis disease [7]. Thus, PLR also has the potential and can act as an 


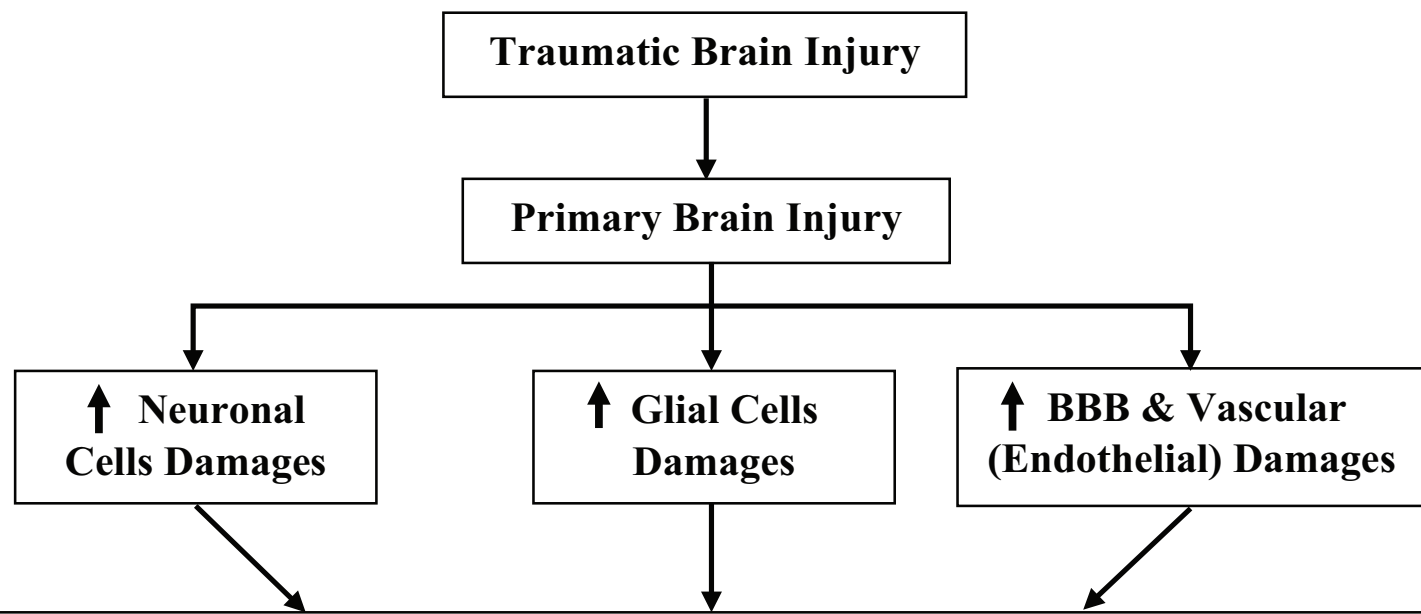

$\uparrow$ Release of TNF-士, IL-1 ${ }^{2}$, IL-6, CXCL1-5, CXCL8-10, GM-CSF, Thrombopoietin, Cortisol

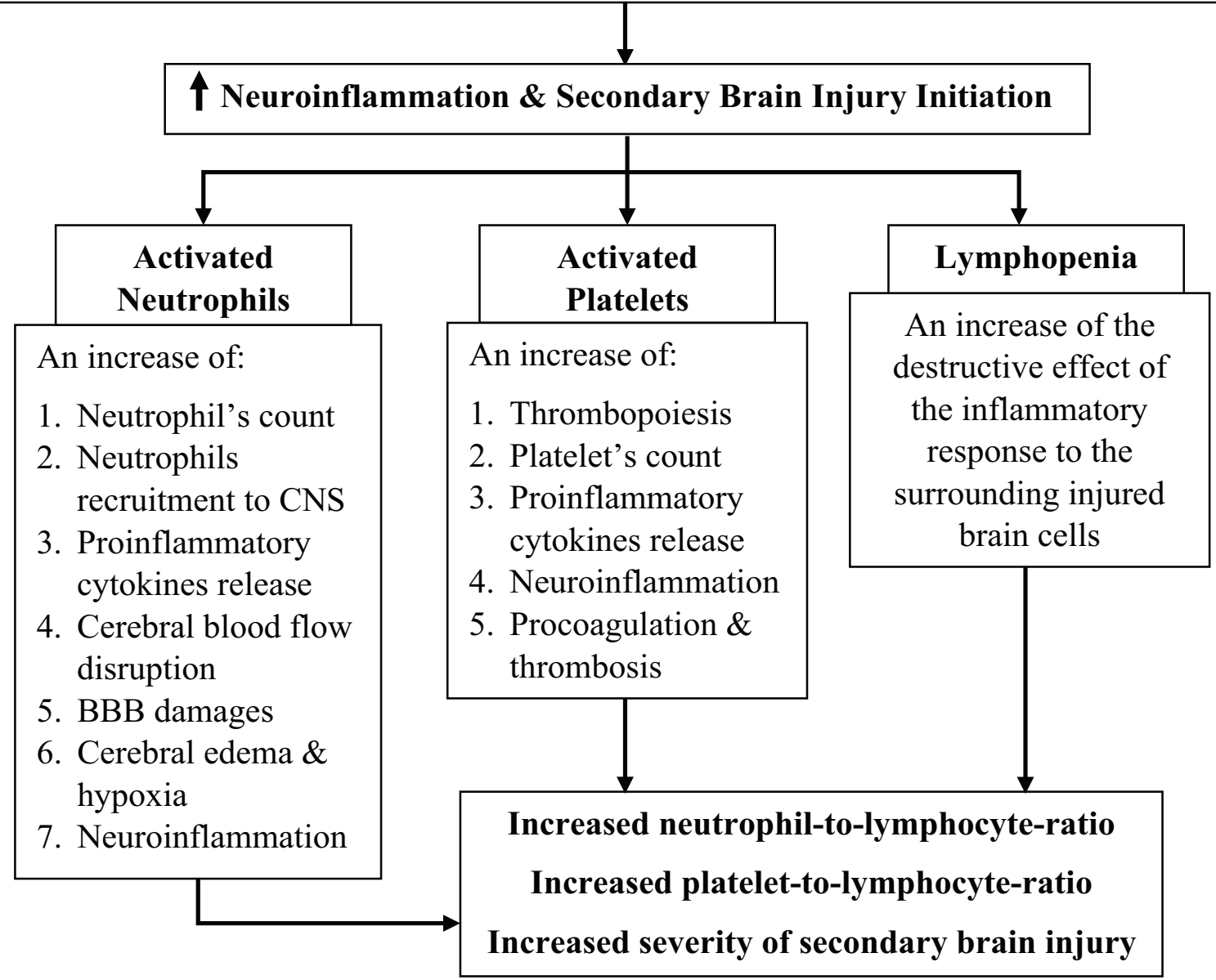

Figure 1: The mechanism of secondary brain injury involving the neutrophil's, platelet's, and lymphocyte's role

inflammatory biomarker in reflecting the severity of $\mathrm{SBI}$ in TBI patients.

\section{Summary}

$\mathrm{SBI}$ is caused by the occurrence of the inflammatory cascades, immune system activity, and inflammation response post-TBI. Neutrophils, platelets, and lymphocytes are involved in the SBI inflammatory reaction post-TBI. In the neuroinflammation process of the SBI, neutrophil's, and platelet's count will increase; meanwhile, the lymphocyte's count will decrease. These processes can increase the NLR and PLR level, which in turn indicate a higher neuroinflammation process, BBB damages, cerebral edema and hypoxia, and cellular damages (oxidative stress and apoptosis/ necrosis of the neurons), so they have an impact on a higher severity level of the SBI process post-TBI postTBI (Figure 1). Thus, the higher the NLR and PLR level, 
the higher the severity level of the SBI. Further studies need to be done to provide more evidence about NLR and PLR in reflecting the severity of the SBI post-TBI.

\section{References}

1. Roozenbeek B, Maas Al, Menon DK. Changing patterns in the epidemiology of traumatic brain injury. Nat Rev Neurol. 2013;9(4):231-6. https://doi.org/10.1038/nrneurol.2013.22

PMid:23443846

2. Shi HY, Hwang SL, Lee KT, Lin CL. Temporal trends and volume-outcome associations after traumatic brain injury: A 12-year study in Taiwan. J Neurosurg. 2013;118(4):732-8. https://doi.org/10.3171/2012.12.jns12693

PMid:23350773

3. Williams $\mathrm{OH}$, Tallantyre EC, Robertson NP. Traumatic brain injury: Pathophysiology, clinical outcome and treatment. J Neurol. 2015;262(5):1394-6. https://doi.org/10.1007/ s00415-015-7741-4

PMid:25904204

4. Werner JK, Stevens RD. Traumatic brain injury: Recent advances in plasticity and regeneration. Curr Opin Neurol.2015;28(6):565-73. https://doi.org/10.1186/ s12974-018-1173-x

PMid:26544030

5. Liu YW, Li S, Dai SS. Neutrophils in traumatic brain injury (TBI): Friend or foe? J Neuroinflammation. 2018;15(1):146. PMid:29776443

6. Walsh KB, Sekar P, Langefeld CD, Moomaw CJ, Elkind MS, Boehme AK, et al. Monocyte count and 30-day case fatality in intracerebral hemorrhage. Stroke. 2015;46(8):2302-4. https:/l doi.org/10.1161/strokeaha.115.009880

PMid:26130090

7. Pan L, Du J, Li T, Liao H. Platelet-to-lymphocyte ratio and neutrophil-to-lymphocyte ratio associated with disease activity in patients with takayasu's arteritis: A case-control study. BMJ Open. 2017;7(4):e014451. https://doi.org/10.1136/ bmjopen-2016-014451

PMid:28473512

8. Azab B, Shah N, Akerman M, McGinn JT Jr. Value of platelet/lymphocyte ratio as a predictor of all-cause mortality after non-ST-elevation myocardial infarction. J Thromb Thrombolysis. 2012;34(3):326-34. https://doi.org/10.1007/ s11239-012-0718-6

PMid:22466812

9. Yin Y, Wang J, Wang X, Gu L, Pei H, Kuai S, et al. Prognostic value of the neutrophil to lymphocyte ratio in lung cancer: A meta-analysis. Clinics. 2015;70(7):524-30. https://doi. org/10.6061/clinics/2015(07)10

10. Tao C, Hu X, Wang J, Ma J, Li H, You C. Admission neutrophil count and neutrophil to lymphocyte ratio predict 90 -day outcome in intracerebral hemorrhage. Biomark Med. 2017;11(1):33-42. https://doi.org/10.2217/bmm-2016-0187

PMid:27917647

11. Wang F, Wang L, Jiang TT, Xia JJ, Xu F, Shen LJ, et al. Neutrophil-to-lymphocyte ratio is an independent predictor of 30-day mortality of intracerebral hemorrhage patients: A validation cohort study. Neurotox Res. 2018;34(3):347-52. https://doi.org/10.1007/s12640-018-9890-6

PMid:29594812
12. Murthy $\mathrm{T}$, Bhatia $\mathrm{P}$, Sandhu $\mathrm{K}$, Prabhakar T, Gogna RL. Secondary brain injury: Prevention and intensive care management. Indian J Neurotrauma. 2005;2(1):7-12. https:// doi.org/10.1016/s0973-0508(05)80004-8

13. Moppett IK. Traumatic brain injury: Assessment, resuscitation and early management. $\mathrm{Br} \mathrm{J}$ Anaesth. 2007;99(1):18-31. https://doi.org/10.1093/bja/aem128

PMid:17545555

14. Aronowski J, Zhao X. Molecular pathophysiology of cerebra hemorrhage: Secondary brain injury. Stroke. 2011;42(6):1781-6. https://doi.org/10.1161/strokeaha.110.596718 PMid:21527759

15. Hazeldine J, Hampson P, Lord JM. The impact of trauma on neutrophil function. Injury. 2014;45(12):1824-33. https://doi. org/10.1016/j.injury.2014.06.021

PMid:25106876

16. Eltzschig HK, Sitkovsky MV, Robson SC. Purinergic signaling during inflammation. N Engl J Med. 2012;367(24):2322-33. https://doi.org/10.1056/nejmra1205750

PMid:23234515

17. Wilson $\mathrm{EH}$, Weninger W, Hunter CA. Trafficking of immune cells in the central nervous system. J Clin Invest. 2010;120(5):136879. https://doi.org/10.1172/jci41911

PMid:20440079

18. Werner C, Engelhard K. Pathophysiology of traumatic brain injury. Br J Anaesth. 2007;99(1):4-9.

PMid:17573392

19. Louveau A, Smirnov I, Keyes TJ, Eccles JD, Rouhan SJ, Peske JD, et al. Structural and functional features of central nervous system lymphatic vessels. Nature. 2015;523(7560):337-41. https://doi.org/10.1038/nature14432 PMid:26030524

20. Hazeldine J, Lord JM, Belli A. Traumatic brain injury and peripheral immune suppression: Primer and prospectus. Front Neurol. 2015;6:235. https://doi.org/10.3389/fneur.2015.00235 PMid:26594196

21. Mantovani A, Cassatella MA, Costantini C, Jaillon $S$ Neutrophils in the activation and regulation of innate and adaptive immunity. Nat Rev Immunol. 2011;11(8):519-31. https://doi.org/10.1038/nri3024

PMid:21785456

22. da Silva FM, Massart-Leen AM, Burvenich C. Development and maturation of neutrophils. Vet Q. 1994;16(4):220-5. https:// doi.org/10.1080/01652176.1994.9694452

PMid: 7740747

23. Beyrau M, Bodkin JV, Nourshargh S. Neutrophil heterogeneity in health and disease: A revitalized avenue in inflammation and immunity. Open Biol. 2012;2(11):120134. https://doi. org/10.1098/rsob.120134

PMid:23226600

24. Khajah M, Millen B, Cara DC, Waterhouse C, McCafferty DM Granulocyte-macrophage colony-stimulating factor (GM-CSF) A chemoattractive agent for murine leukocytes in vivo. J Leukoc Biol. 2011;89(6):945-53. https://doi.org/10.1189/jlb.0809546 PMid:21393420

25. Cowland JB, Borregaard N. The individual regulation of granule protein mRNA levels during neutrophil maturation explains the heterogeneity of neutrophil granules. J Leukoc Biol. 1999;66(6):989-95. https://doi.org/10.1002/jlb.66.6.989

PMid:10614782

26. Min H, Hong J, Cho IH, Jang YH, Lee H, Kim D, et al. TLR2induced astrocyte MMP9 activation compromises the blood brain barrier and exacerbates intracerebral hemorrhage in animal models. Mol Brain. 2015;8:23. https://doi.org/10.1186/ 
s13041-015-0116-z

PMid:25879213

27. Lu KT, Wang YW, Yang JT, Yang YL, Chen HI. Effect of interleukin-1 on traumatic brain injury-induced damage to hippocampal neurons. J Neurotrauma. 2005;22(8):885-95. https://doi.org/10.1089/neu.2005.22.885

PMid:16083355

28. Johnson EA, Dao TL, Guignet MA, Geddes CE, Koemeter-Cox Al, Kan RK. Increased expression of the chemokines CXCL1 and MIP-1alpha by resident brain cells precedes neutrophil infiltration in the brain following prolonged soman-induced status epilepticus in rats. J Neuroinflammation. 2011;8:41. https://doi.org/10.1186/1742-2094-8-41

PMid:21535896

29. Allport JR, Ding H, Collins T, Gerritsen ME, Luscinskas FW. Endothelial-dependent mechanisms regulate leukocyte transmigration: A process involving the proteasome and disruption of the vascular endothelial-cadherin complex at endothelial cell-to-cell junctions. J Exp Med. 1997;186(4):51727. https://doi.org/10.1084/jem.186.4.517 PMid:9254650

30. Bolton SJ, Anthony DC, Perry VH. Loss of the tight junction proteins occludin and zonula occludens- 1 from cerebral vascular endothelium during neutrophil-induced blood-brain barrier breakdown in vivo. Neuroscience. 1998;86(4):1245-57. https://doi.org/10.1016/s0306-4522(98)00058-x

PMid:9697130

31. Grossetete M, Phelps J, Arko L, Yonas H, Rosenberg GA Elevation of matrix metalloproteinases 3 and 9 in cerebrospinal fluid and blood in patients with severe traumatic brain injury. Neurosurgery. 2009;65(4):702-8. https://doi.org/10.1227/01. neu.0000351768.11363.48

PMid:19834375

32. Hayashi T, Kaneko Y, Yu S, Bae E, Stahl CE, Kawase T, et al Quantitative analyses of matrix metalloproteinase activity after traumatic brain injury in adult rats. Brain Res. 2009;1280:172 7. https://doi.org/10.1016/j.brainres.2009.05.040 PMid:19464272

33. Pun PB, Lu J, Moochhala S. Involvement of ROS in BBB dysfunction. Free Radic Res. 2009;43(4):348-64.

PMid:19241241

34. Liu X, Sui B, Sun J. Blood-brain barrier dysfunction induced by silica NPs in vitro and in vivo: Involvement of oxidative stress and Rho-kinase/JNK signaling pathways. Biomaterials. 2017;121:64-82. https://doi.org/10.1016/j. biomaterials.2017.01.006

PMid:28081460

35. Qureshi Al, Suarez Jl. Use of hypertonic saline solutions in treatment of cerebral edema and intracranial hypertension. Crit Care Med. 2000;28(9):3301-13. https://doi. org/10.1097/00003246-200009000-00032 PMid:11008996

36. Klatzo I. Pathophysiological aspects of brain edema. Acta Neuropathol. 1987;72(3):236-9. https://doi.org/10.1007/ bf00691095

PMid:3564903

37. Edens HA, Parkos CA. Neutrophil transendothelial migration and alteration in vascular permeability: Focus on neutrophilderived azurocidin. Curr Opin Hematol. 2003;10(1):25-30 https://doi.org/10.1097/00062752-200301000-00005 PMid:12483108

38. Ikegame $\mathrm{Y}$, Yamashita $\mathrm{K}$, Hayashi $\mathrm{S}$, Yoshimura $\mathrm{S}$, Nakashima S, Iwama T. Neutrophil elastase inhibitor prevents ischemic brain damage via reduction of vasogenic edema. Hypertens Res. 2010;33(7):703-7. https://doi.org/10.1038/

\section{hr.2010.58}

PMid:20485441

39. De Y, Chen Q, Schmidt AP, Anderson GM, Wang JM, Wooters J et al. LL-37, the neutrophil granule-and epithelial cell-derived cathelicidin, utilizes formyl peptide receptor-like 1 (FPRL1) as a receptor to chemoattract human peripheral blood neutrophils, monocytes, and T cells. J Exp Med. 2000;192(7):1069-74. https://doi.org/10.1084/jem.192.7.1069

PMid:11015447

40. Walmsley SR, Print C, Farahi N, Peyssonnaux C, Johnson RS Cramer T, et al. Hypoxia-induced neutrophil survival is mediated by HIF-1alpha-dependent NF-kappaB activity. J Exp Med. 2005;201(1):105-15. https://doi.org/10.1084/jem.20040624 PMid:15630139

41. Taylor PR, Roy S, Leal SM Jr., Sun Y, Howell SJ, Cobb BA et al. Activation of neutrophils by autocrine IL-17A-IL-17RC interactions during fungal infection is regulated by IL-6, IL-23, RORgammat and dectin-2. Nat Immunol. 2014;15(2):143-51. https://doi.org/10.1038/ni.2797

PMid:24362892

42. Chang JJ, Youn TS, Benson D, Mattick H, Andrade N, Harper CR, et al. Physiologic and functional outcome correlates of brain tissue hypoxia in traumatic brain injury. Crit Care Med. 2009;37(1):283-90. https://doi.org/10.1097/ ccm.0b013e318192fbd7

PMid:19050612

43. Kumar A, Loane DJ. Neuroinflammation after traumatic brain injury: Opportunities for therapeutic intervention. Brain Behav Immun. 2012;26(8):1191-201. https://doi.org/10.1016/j. bbi.2012.06.008

PMid:22728326

44. Zhou H, Lapointe BM, Clark SR, Zbytnuik L, Kubes P. A requirement for microglial TLR4 in leukocyte recruitment into brain in response to lipopolysaccharide. $J$ Immunol. 2006;177(11):8103-10. https://doi.org/10.4049/ jimmunol.177.11.8103

PMid: 17114485

45. Loane DJ, Kumar A. Microglia in the TBI brain: The good, the bad, and the dysregulated. Exp Neurol. 2016;275(3):316-27. https://doi.org/10.1016/j.expneurol.2015.08.018 PMid:26342753

46. Qin L, Li G, Qian X, Liu Y, Wu X, Liu B, et al. Interactive role of the toll-like receptor 4 and reactive oxygen species in LPSinduced microglia activation. Glia. 2005;52(1):78-84. https:// doi.org/10.1002/glia.20225

PMid:15920727

47. Jang E, Lee S, Kim JH, Kim JH, Seo JW, Lee WH, et al. Secreted protein lipocalin-2 promotes microglial M1 polarization. FASEB J. 2013;27(3):1176-90. https://doi.org/10.1096/fj.12-222257

PMid:23207546

48. McPherson CA, Merrick BA, Harry GJ. In vivo molecular markers for pro-inflammatory cytokine M1 stage and resident microglia in trimethyltin-induced hippocampal injury. Neurotox Res. 2014;25(1):45-56. https://doi.org/10.1007/s12640-013-9422-3 PMid:24002884

49. Kalish $\mathrm{H}$, Phillips TM. Application of immunoaffinity capillary electrophoresis to the measurements of secreted cytokines by cultured astrocytes. J Sep Sci. 2009;32(10):1605-12. https:// doi.org/10.1002/jssc.200900047

PMid:19472286

50. Pineau I, Sun L, Bastien D, Lacroix S. Astrocytes initiate inflammation in the injured mouse spinal cord by promoting the entry of neutrophils and inflammatory monocytes in an IL-1 receptor/MyD88-dependent fashion. Brain Behav Immun. 2010;24(4):540-53. https://doi.org/10.1016/j.bbi.2009.11.007 


\section{PMid:19932745}

51. Fang J, Han D, Hong J, Tan Q, Tian Y. The chemokine, macrophage inflammatory protein-2gamma, reduces the expression of glutamate transporter-1 on astrocytes and increases neuronal sensitivity to glutamate excitotoxicity. J Neuroinflammation. 2012;9:267. https://doi. org/10.1186/1742-2094-9-267

PMid:23234294

52. Liu Z, Chopp M. Astrocytes, therapeutic targets for neuroprotection and neurorestoration in ischemic stroke. Prog Neurobiol. 2016;144:103-20 https://doi.org/10.1016/j. pneurobio.2015.09.008

PMid:26455456

53. Hu S, Sheng WS, Ehrlich LC, Peterson PK, Chao CC. Cytokine effects on glutamate uptake by human astrocytes. Neuroimmunomodulation. 2000;7(3):153-9. https://doi. org/10.1159/000026433

PMid:10754403

54. Luheshi NM, Kovacs KJ, Lopez-Castejon G, Brough D, Denes A. Interleukin-1alpha expression precedes IL-1beta after ischemic brain injury and is localised to areas of focal neuronal loss and penumbral tissues. J Neuroinflammation. 2011;8:186. https://doi.org/10.1186/1742-2094-8-186 PMid:22206506

55. Mesples B, Fontaine RH, Lelievre V, Launay JM, Gressens P. Neuronal TGF-beta1 mediates IL-9/mast cell interaction and exacerbates excitotoxicity in newborn mice. Neurobiol Dis. 2005;18(1):193-205. https://doi.org/10.1016/j.nbd.2004.09.018 PMid:15649710

56. Fortin CF, Ear T, McDonald PP. Autocrine role of endogenous interleukin-18 on inflammatory cytokine generation by human neutrophils. FASEB J. 2009;23(1):194-203. https://doi. org/10.1096/fj.08-110213

\section{PMid:18780764}

57. Shichita $T$, Sugiyama $Y$, Ooboshi $H$, Sugimori $H$, Nakagawa $R$, Takada I, et al. Pivotal role of cerebral interleukin-17-producing gammadelta $T$ cells in the delayed phase of ischemic brain injury. Nat Med. 2009;15(8):946-50. https://doi.org/10.1038/ nm.1999

\section{PMid:19648929}

58. Omatsu T, Cepinskas G, Clarson C, Patterson EK, Alharfi IM, Summers K, et al. CXCL1/CXCL8 (GROalpha/IL-8) in human diabetic ketoacidosis plasma facilitates leukocyte recruitment to cerebrovascular endothelium in vitro. Am J Physiol Endocrinol Metab. 2014;306(9):E1077-84. https://doi. org/10.1152/ajpendo.00659.2013

PMid:24619879

59. Rhodes JK, Sharkey J, Andrews PJ. The temporal expression, cellular localization, and inhibition of the chemokines MIP-2 and MCP-1 after traumatic brain injury in the rat. J Neurotrauma. 2009;26(4):507-25. https://doi.org/10.1089/neu.2008.0686 PMid: 19210118

60. Szmydynger-Chodobska J, Strazielle N, Zink BJ, GhersiEgea JF, Chodobski A. The role of the choroid plexus in neutrophil invasion after traumatic brain injury. J Cereb Blood Flow Metab. 2009;29(9):1503-16. https://doi.org/10.1038/ jcbfm.2009.71

PMid:19471279

61. Wang LY, Tu YF, Lin YC, Huang CC. CXCL5 signaling is a shared pathway of neuroinflammation and blood-brain barrier injury contributing to white matter injury in the immature brain. J Neuroinflammation. 2016;13:6. https://doi.org/10.1186/ s12974-015-0474-6

PMid:26738635

62. Semple BD, Kossmann T, Morganti-Kossmann MC. Role of chemokines in CNS health and pathology: A focus on the CCL2/CCR2 and CXCL8/CXCR2 networks. J Cereb Blood Flow Metab. 2010;30(3):459-73. https://doi.org/10.1038/ jcbfm.2009.240

PMid:19904283

63. Imai $\mathrm{Y}$, Kohsaka S. Intracellular signaling in M-CSF-induced microglia activation: Role of Iba1. Glia. 2002;40(2):164-74 https://doi.org/10.1002/glia.10149

PMid:12379904

64. Nguyen HX, O'Barr TJ, Anderson AJ. Polymorphonuclear leukocytes promote neurotoxicity through release of matrix metalloproteinases, reactive oxygen species, and TNFalpha. J Neurochem. 2007;102(3):900-12. https://doi. org/10.1111/j.1471-4159.2007.004643.x

PMid:17561941

65. Rosell A, Cuadrado E, Ortega-Aznar A, HernandezGuillamon M, Lo EH, Montaner J. MMP-9-positive neutrophil infiltration is associated to blood-brain barrier breakdown and basal lamina Type IV collagen degradation during hemorrhagic transformation after human ischemic stroke. Stroke. 2008;39(4):1121-6. https://doi.org/10.1161/ strokeaha.107.500868

PMid:18323498

66. Matsuo $Y$, Onodera $H$, Shiga $Y$, Nakamura $M$, Ninomiya $M$, Kihara T, et al. Correlation between myeloperoxidase-quantified neutrophil accumulation and ischemic brain injury in the rat. Effects of neutrophil depletion. Stroke. 1994;25(7):1469-75. https://doi.org/10.1161/01.str.25.7.1469

PMid:8023364

67. Luo CL, Chen XP, Yang R, Sun YX, Li QQ, Bao HJ, et al Cathepsin $B$ contributes to traumatic brain injury-induced cell death through a mitochondria-mediated apoptotic pathway. $J$ Neurosci Res. 2010;88(13):2847-58. https://doi.org/10.1002/ jnr.22453

PMid:20653046

68. Semple BD, Trivedi A, Gimlin K, Noble-Haeusslein LJ. Neutrophil elastase mediates acute pathogenesis and is a determinant of long-term behavioral recovery after traumatic injury to the immature brain. Neurobiol Dis. 2015;74:263-80. https://doi.org/10.1016/j.nbd.2014.12.003

PMid:25497734

69. Au BT, Williams TJ, Collins PD. Zymosan-induced IL-8 release from human neutrophils involves activation via the $C D 11 b /$ CD18 receptor and endogenous platelet-activating factor as an autocrine modulator. J Immunol. 1994;152(11):5411-9.

PMid:7514637

70. Surette ME, Krump E, Picard S, Borgeat P. Activation of leukotriene synthesis in human neutrophils by exogenous arachidonic acid: Inhibition by adenosine $\mathrm{A}(2 \mathrm{a})$ receptor agonists and crucial role of autocrine activation by leukotriene B(4). Mol Pharmacol. 1999;56(5):1055-62. https://doi. org $/ 10.1124 / \mathrm{mol} .56 .5 .1055$

PMid:10531413

71. Cho SY, Jeon YL, Kim W, Kim WS, Lee HJ, Lee WI, et al. Mean platelet volume and mean platelet volume/platelet count ratio in infective endocarditis. Platelets. 2014;25(8):559-61. https:// doi.org/10.3109/09537104.2013.857394

PMid:24205785

72. Gasparyan AY, Ayvazyan L, Mikhailidis DP, Kitas GD. Mean platelet volume: A link between thrombosis and inflammation? Curr Pharm Des. 2011;17(1):47-58. https://doi. org/10.2174/138161211795049804

PMid:21247392

73. Kaushansky K. The molecular mechanisms that control thrombopoiesis. J Clin Invest. 2005;115(12):3339-47. https:// 
doi.org/10.1172/jci26674

PMid:16322778

74. Kaushansky K. Lineage-specific hematopoietic growth factors. N Engl J Med. 2006;354(19):2034-45. https://doi.org/10.1056/ nejmra052706

PMid:16687716

75. Kim CH, Kim SJ, Lee MJ, Kwon YE, Kim YL, Park KS, et al. An increase in mean platelet volume from baseline is associated with mortality in patients with severe sepsis or septic shock. PLoS One. 2015;10(3):e0119437. https://doi.org/10.1371/ journal.pone. 0119437

PMid:25742300

76. Nording HM, Seizer P, Langer HF. Platelets in inflammation and atherogenesis. Front Immunol. 2015;6:98. https://doi. org/10.3389/fimmu.2015.00098

PMid:25798138

77. Zhang W, Shen Y. Platelet-to-lymphocyte ratio as a new predictive index of neurological outcomes in patients with acute intracranial hemorrhage: A retrospective study. Med Sci Monit. 2018;24:4413-20. https://doi.org/10.12659/msm.910845 PMid:29946059

78. El Haouari M, Rosado JA. Platelet signalling abnormalities in patients with Type 2 diabetes mellitus: A review. Blood Cells Mol Dis. 2008;41(1):119-23. https://doi.org/10.1016/j. bcmd.2008.02.010

PMid:18387322

79. van der Loo B, Martin JF. A role for changes in platelet production in the cause of acute coronary syndromes. Arterioscler Thromb Vasc Biol. 1999;19(3):672-9. https://doi.org/10.1161/01. atv.19.3.672

PMid:10073972

80. Miyazaki H, Kato T. Thrombopoietin: Biology and clinical potentials. Int J Hematol. 1999;70(4):216-25.

PMid:10643146

81. Thompson CB, Jakubowski JA. The pathophysiology and clinical relevance of platelet heterogeneity. Blood. 1988;72(1):18. https://doi.org/10.1182/blood.v72.1.1.bloodjournal7211 PMid:3291975

82. Alexandrakis MG, Passam FH, Perisinakis K, Ganotakis E, Margantinis G, Kyriakou DS, et al. Serum proinflammatory cytokines and its relationship to clinical parameters in lung cancer patients with reactive thrombocytosis. Respir Med. 2002;96(8):553-8. https://doi.org/10.1053/rmed.2002.1328

PMid:12195834

83. Alexandrakis MG, Passam FH, Moschandrea IA, Christophoridou AV, Pappa CA, Coulocheri SA, et al. Levels of serum cytokines and acute phase proteins in patients with essential and cancer-related thrombocytosis. Am J Clin Oncol. 2003;26(2):135-40. https://doi.org/10.1097/01. coc.0000017093.79897.de

PMid:12714883

84. Habets KL, Trouw LA, Levarht EW, Korporaal SJ, Habets PA, de Groot $P$, et al. Anti-citrullinated protein antibodies contribute to platelet activation in rheumatoid arthritis. Arthritis Res Ther. 2015;17(1):209. https://doi.org/10.1186/s13075-015-0665-7 PMid:26268317

85. Akboga MK, Canpolat U, Yayla C, Ozcan F, Ozeke O, Topaloglu S, et al. Association of platelet to lymphocyte ratio with inflammation and severity of coronary atherosclerosis in patients with stable coronary artery disease. Angiology. 2016;67(1):89-95. https://doi.org/10.1177/0003319715583186 PMid:25922197

86. Palatinus A, Adams M. Thrombosis in systemic lupus erythematosus. Semin Thromb Hemost. 2009;35(7):621-9. https://doi.org/10.1055/s-0029-1242716

PMid:20013529

87. Boilard E, Nigrovic PA, Larabee K, Watts GF, Coblyn JS, Weinblatt ME, et al. Platelets amplify inflammation in arthritis via collagen-dependent microparticle production. Science. 2010;327(5965):580-3. https://doi.org/10.1126/ science. 1181928

PMid:20110505

88. Gasparyan AY, Stavropoulos-Kalinoglou A, Mikhailidis DP, Douglas KM, Kitas GD. Platelet function in rheumatoid arthritis: Arthritic and cardiovascular implications. Rheumatol Int 2011;31(2):153-64. https://doi.org/10.1007/s00296-010-1446-x PMid:20390282

89. Aksu K, Donmez A, Keser G. Inflammation-induced thrombosis: Mechanisms, disease associations and management. Curr Pharm Des. 2012;18(11):1478-93. https:// doi.org/10.2174/138161212799504731

PMid:22364132

90. Colkesen $\mathrm{Y}$, Muderrisoglu $\mathrm{H}$. The role of mean platelet volume in predicting thrombotic events. Clin Chem Lab Med. 2012;50(4):631-4. https://doi.org/10.1515/cclm.2011.806 PMid:22112054

91. Thomson SP, McMahon LJ, Nugent CA. Endogenous cortisol: A regulator of the number of lymphocytes in peripheral blood Clin Immunol Immunopathol. 1980;17(4):506-14. https://doi. org/10.1016/0090-1229(80)90146-4

PMid:7192197

92. Zouridakis EG, Garcia-Moll X, Kaski JC. Usefulness of the blood lymphocyte count in predicting recurrent instability and death in patients with unstable angina pectoris. Am J Cardiol. 2000;86(4):449-51. https://doi.org/10.1016/ s0002-9149(00)00963-2

PMid:10946041

93. Niederhuber JE. Cancer vaccines: The molecular basis for $T$ cell killing of tumor cells. Oncologist. 1997;2(5):280-3. https:// doi.org/10.1634/theoncologist.2-5-280

PMid:10388060

94. Xue M, Del Bigio MR. Comparison of brain cell death and inflammatory reaction in three models of intracerebral hemorrhage in adult rats. J Stroke Cerebrovasc Dis. 2003;12(3):152-9. https://doi.org/10.1016/ s1052-3057(03)00036-3

PMid:17903920

95. Ye Z, Ai X, Fang F, Hu X, Faramand A, You C. The use of neutrophil to lymphocyte ratio as a predictor for clinical outcomes in spontaneous intracerebral hemorrhage. Oncotarget. 2017;8(52):90380-9. https://doi.org/10.18632/ oncotarget. 20120

PMid:29163837

96. Liao Y, Liu P, Guo F, Zhang ZY, Zhang Z. Oxidative burst of circulating neutrophils following traumatic brain injury in human. PLoS One. 2013;8(7):e68963. https://doi.org/10.1371/journal. pone. 0068963

PMid:23894384

97. Roth TL, Nayak D, Atanasijevic T, Koretsky AP, Latour LL, McGavern DB. Transcranial amelioration of inflammation and cell death after brain injury. Nature. 2014;505(7482):223-8. https://doi.org/10.1038/nature12808

PMid:24317693

98. Zhou Y, Wang Y, Wang J, Stetler RA, Yang QW. Inflammation in intracerebral hemorrhage: From mechanisms to clinical translation. Prog Neurobiol. 2014;115:25-44. https://doi. org/10.1016/j.pneurobio.2013.11.003

PMid:24291544 
99. Hu ZD, Sun Y, Guo J, Huang YL, Qin BD, Gao Q, et al. Red blood cell distribution width and neutrophil/lymphocyte ratio are positively correlated with disease activity in primary sjogren's syndrome. Clin Biochem. 2014;47(18):287-90. https://doi. org/10.1016/j.clinbiochem.2014.08.022

PMid:25204965

100. Rifaioglu EN, Bülbül ŞB, Ekiz Ö, Cigdem DA. Neutrophil to lymphocyte ratio in behçet's disease as a marker of disease activity. Acta Dermatovenerol Alp Pannonica Adriat. 2014;23(4):65-7. https://doi.org/10.15570/actaapa.2014.16z PMid:25527038

101. Uslu AU, Kucuk A, Sahin A, Ugan Y, Yilmaz R, Gungor T, et al. Two new inflammatory markers associated with disease activity score-28 in patients with rheumatoid arthritis: Neutrophillymphocyte ratio and platelet-lymphocyte ratio. Int J Rheum Dis. 2015;18(7):731-5. https://doi.org/10.1111/1756-185x.12582

PMid:25900081

102. Gao SQ, Huang LD, Dai RJ, Chen DD, Hu WJ, Shan YF Neutrophil-lymphocyte ratio: A controversial marker in predicting Crohn's disease severity. Int J Clin Exp Pathol. 2015;8(11):14779-85.

PMid:26823804

103. Toprak AE, Ozlu E, Uzuncakmak TK, Yalcinkaya E, Sogut S, Karadag AS. Neutrophil/lymphocyte ratio, serum endocan, and nesfatin-1 levels in patients with psoriasis vulgaris undergoing phototherapy treatment. Med Sci Monit. 2016;22:1232-7. https://doi.org/10.12659/msm.898240

PMid:27070789

104. Chen W, Yang J, Li B, Peng G, Li T, Li L, et al. Neutrophil to lymphocyte ratio as a novel predictor of outcome in patients with severe traumatic brain injury. J Head Trauma Rehabil. 2018;33(1):E53-9. https://doi.org/10.1097/ htr.0000000000000320

PMid:28520670
105. Chen J, Qu X, Li Z, Zhang D, Hou L. Peak neutrophilto-lymphocyte ratio correlates with clinical outcomes in patients with severe traumatic brain injury. Neurocrit Care. 2019;30(2):334-9. https://doi.org/10.1007/s12028-018-0622-9 PMid:30288677

106. Zhao JL, Du ZY, Yuan Q, Yu J, Sun YR, Wu X, et al. Prognostic value of neutrophil-to-lymphocyte ratio in predicting the 6-month outcome of patients with traumatic brain injury: A retrospective study. World Neurosurg. 2019;124:e411-6. https://doi.org/10.1016/j.wneu.2018.12.107

PMid:30610986

107. Kundi $H$, Balun $A$, Cicekcioglu $H$, Cetin M, Kiziltunc $E$, Cetin ZG, et al. The relation between platelet-to-lymphocyte ratio and pulmonary embolism severity index in acute pulmonary embolism. Heart Lung. 2015;44(4):340-3. https:// doi.org/10.1016/j.hrtlng.2015.04.007

PMid:25998993

108. Cetin EH, Cetin MS, Aras D, Topaloglu S, Temizhan A, Kisacik HL, et al. Platelet to lymphocyte ratio as a prognostic marker of in-hospital and long-term major adverse cardiovascular events in ST-segment elevation myocardial infarction. Angiology. 2016;67(4):336-45. https://doi. org/10.1177/0003319715591751

PMid:26101368

109. Zhang F, Chen Z, Wang P, Hu X, Gao Y, He J. Combination of platelet count and mean platelet volume (COP-MPV) predicts postoperative prognosis in both resectable early and advanced stage esophageal squamous cell cancer patients. Tumour Biol. 2016;37(7):9323-31. https://doi.org/10.1007/ s13277-015-4774-3

PMid:26779631

110. Balta S, Demirkol S, Kucuk U. The platelet lymphocyte ratio may be useful inflammatory indicator in clinical practice. Hemodial Int. 2013;17(4):668-9. https://doi.org/10.1111/hdi.12058 PMid:23763539 